\title{
Deteksi transmisi transovarial virus dengue pada Aedes aegypti dengan teknik imunositokimia di Kota Manado
}

\author{
${ }^{1}$ Lidiasani P. Mosesa \\ ${ }^{2}$ Angle Sorisi \\ ${ }^{2}$ Victor D. Pijoh
}

\author{
${ }^{1}$ Kandidat Skripsi Fakultas Kedokteran Universitas Sam Ratulangi Manado \\ ${ }^{2}$ Bagian Parasitologi Klinik Fakultas Kedokteran Universitas Sam Ratulangi Manado \\ Email: lidia_sweet17@yahoo.com
}

\begin{abstract}
Capability of Dengue virus to maintain its existence by two mechanism, that is horizontal transmission between veremia vertebrata that contracted by Aedes mosquito and vertical transmission from female mosquito infective to next generation. The most mechanism common occurrence is vertical transmission whereabout of transovarial transmission can be detected by many kind of way, one of way is immunositochemical technic. Immunositochemical is reported to be able detect antigen Dengue virus in low level. This research aims to prove whereabout of transovarial transmission Dengue virus on Aedes aegypti in Manado city. Researche sampel is Aedes aegypti mosquitos from eggs Aedes aegypti that was taken from urban village that is DBD case. This research was held on November 2015 January 2016. Research result show that Aedes aegypti mosquito antigen positive Dengue are 24 tail of mosquitos from 48 tail of mosquitos that was tested with Index Transmissi Transovarial (ITT) about 39,1\% - 70\%. Based on research result can be proven that there is transovarial transmission Dengue virus on Aedes aegypti in West Kombos Urban Village, Singkil Distric, Manado City.
\end{abstract}

Keywords: transovarial transmission, dengue virus, aedes aegypti, immunositochemical technic

\begin{abstract}
Abstrak: Kemampuan Virus Dengue untuk mempertahankan keberadaannya melalui dua mekanisme yaitu transmisi horizontal antara vertebrata viremia yang ditularkan oleh nyamuk Aedes dan transmisi vertikal (transovarial) yaitu dari nyamuk betina infektif ke generasi berikutnya. Mekanisme yang paling umum terjadi adalah transmisi vertikal (transovarial). Ada tidaknya transmisi transovarial dapat diketahui dengan berbagai cara, salah satunya dengan teknik imunositokimia. Metode imunositokimia dilaporkan dapat mendeteksi antigen virus Dengue dalam kadar yang rendah. Penelitian ini bertujuan untuk membuktikan ada tidaknya transmisi transovarial virus Dengue pada Aedes aegypti di kota Manado. Sampel penelitian adalah nyamuk Aedes aegypti yang berasal dari telur Aedes yang diambil dari kelurahan yang terdapat kasus DBD. Penelitian ini dilaksanakan pada bulan November 2015 - Januari 2016. Hasil penelitian menunjukkan bahwa nyamuk Aedes aegypti yang positif antigen virus Dengue berjumlah 24 ekor nyamuk dari 48 ekor nyamuk yang diperiksa dengan Index Transmisi Transovarial (ITT) berkisar 39,1\% - 70\%. Berdasarkan hasil penelitian tersebut, terbukti bahwa adanya transmisi transovarial virus Dengue pada Aedes aegypti di Kelurahan Kombos Barat Kecamatan Singkil, Kota Manado.
\end{abstract}

Kata kunci: transmisi transovarial, virus dengue, aedes aegypti, teknik imunositokimia

Demam berdarah dengue (DBD) atau Dengue Hemorrhagic Fever (DHF) adalah suatu penyakit yang disebabkan oleh virus Dengue, merupakan arbovirus dan 
termasuk dalam family Flaviviridae. ${ }^{1}$ Vektor utama DBD adalah nyamuk rumah yang disebut Aedes aegypti, ${ }^{2}$ yang ditularkan dari orang ke orang melalui gigitan nyamuk Aedes dari subgenuk Stegomyia. ${ }^{1}$

Berdasarkan Data dan Informasi Kementerian Kesehatan Indonesia tahun 2014, persentase jumlah kab/kota tahun 2014 mengalami peningkatan sebesar 84,74/497 kab/kota. ${ }^{3}$

Di kota Manado tahun 2013, di kecamatan Singkil sebanyak 43 kasus demam berdarah dengue. ${ }^{4}$ Berdasarkan survei data tahun 2015, di wilayah kerja Puskesmas Kombos Kecamatan Singkil terdapat empat kasus DBD di Kelurahan Kombos Barat Kecamatan Singkil.

Diketahui penularan virus Dengue dari gigitan nyamuk Aedes aegypti yang semula menggigit orang yang terinfeksi virus Dengue dan menularkan melalui gigitan ke orang yang tidak terinfeksi virus Dengue. Tetapi ada juga kasus DBD yang muncul saat tidak ada kasus DBD sebelumnya. Hal ini diduga karena adanya transmisi transovarial virus dengue pada vektor demam berdarah dengue.

Penelitian adanya penularan transovarial virus Dengue pada nyamuk Aedes pernah dilakukan di Malalayang Kota Manado pada tahun 2013, dengan index transmisi transovarial (ITT) berkisar 6,117,1\%. Penelitian ini membuktikan adanya transmisi transovarial virus Dengue pada nyamuk Aedes di kabupaten Malalayang, dan ITT Aedes aegypti lebih tinggi dibandingkan dengan Aedes albopictus, serta tidak ada hubungan yang signifikan antara ITT dan angka insidensi DBD. ${ }^{6}$

Ada tidaknya transmisi transovarial dapat diketahui dengan menggunakan teknik imunositokimia. Virus Dengue juga dapat dideteksi dengan menggunakan metode lain, antara lain immunofluorescence, immunoperoxydase, atau polymerase chain reaction (PCR). Penelitian deteksi virus Dengue dengan menggunakan Reverse Transcription PCR (RT-PCR) dilaporkan oleh Andi Mulia, yaitu di kota Medan. ${ }^{7}$
Berdasarkan penelitian tentang sensitivitas dan spesifitas antibodi monoklonal DSSE10 pada Head Squash Toxorhynchites Splendens dengan teknik imunohistokimia yang dilaporkan oleh Sari dan Umniyati, imunohistokimia SBPC memiliki keunggulan dibandingkan dengan RT-PCR, antara lain tidak membutuhkan peralatan laboratorium yang mahal sehingga bisa dilakukan di setiap laboratorium yang memiliki mikroskop cahaya, biaya pemeriksaan lebih murah dan preparat head squash dapat disimpan dalam jangka waktu yang lama. ${ }^{1}$

Penelitian ini bertujuan untuk membuktikan ada tidaknya transmisi transovarial virus Dengue pada Aedes aegypti di Kelurahan Kombos Barat Kecamatan Singkil kota Manado. Dengan mengetahui adanya transmisi transovarial pada nyamuk Aedes aegypti, diharapkan mampu mendukung kewaspadaan dini demi terlaksanya program pengendalian dan pencegahan DBD.

\section{BAHAN DAN CARA}

Penelitian ini menggunakan desain deskriptif. Penelitian dilakukan di Kelurahan Kombos Barat Kecamatan Singkil Kota Manado bulan Desember 2015. Sampel nyamuk yang akan dideteksi dikoleksi pada telur dari hasil penangkapan telur yang telah dilakukan.

\section{Penangkapan telur dan kolonisasi nyamuk $^{5}$}

Penangkapan telur dilakukan sebanyak satu kali dengan menggunakan ovitrap. Daerah penangkapan di sekitar tempat tinggal kasus DBD. Ovitrap dipasang pada empat rumah di dalam dan luar rumah tempat tinggal kasus DBD selama tiga hari. Pada hari ketiga, ovitrap diambil dan dipindahkan dalam nampan berisi air. Telur yang diperoleh dalam satu rumah dipelihara dalam satu nampan dan diberi label, serta dibiarkan selama dua sampai tiga hari. Pemeliharaan telur dilakukan di Laboratorium Parasitologi Klinik Fakultas Kedokteran UNSRAT. Setelah telur menetas menjadi larva selanjutnya diberi 
pakan hati ayam yang dihaluskan. Apabila sudah menjadi nyamuk dewasa, nyamuk diberi pakan berupa larutan gula 10\% tanpa diberi kesempatan untuk menghisap darah. Setelah berumur 8 hari, nyamuk dimatikan dengan cara dimasukkan dalam freezer selama 5 menit, kemudian diidentifikasi dengan menggunakan lup untuk memisahkan nyamuk Aedes aegypti dari nyamuk lainnya yang ikut tertangkap.

\section{Pemeriksaan imunositokimia pada nyamuk $^{1}$}

Nyamuk yang telah dimatikan dalam freezer dan diidentifikasi, kemudian dipisahkan thorax dan caput menggunakan jarum dan pinset dissecting. Bagian caput nyamuk diletakkan pada kaca sediaan yang bersih. Setiap kaca sediaan berisi 10 buah caput nyamuk. Caput nyamuk ditekantekan di bawah kaca penutup menggunakan ujung tangkai jarum dissecting. Kaca penutup diambil lalu ditetesi metanol dingin $\left(-20^{\circ} \mathrm{C}\right)$ sampai semua bagian tergenang dan diinkubasi selama 5 menit, setelah preparat kering, dicuci dengan aquades. Sediaan ditetesi peroxidase blocking solution $100 \mu \mathrm{l} /$ preparat dan diinkubasi pada suhu kamar selama 10 menit. Lalu, dicuci dengan air mengalir serta dibilas dengan aquades. Sediaan ditiriskan, lalu ditetesi antibodi primer (antibodi monoclonal DSSE10 !:5) sebanyak $50 \mu \mathrm{l} /$ preparat dan diinkubasi pada nampan yang lembap yang ditutup alumunium foil pada suhu kamar selama 60 menit. Sediaan dicuci dengan PBS 3 kali masing-masing waktu pencucian selama 2 menit, kemudian ditiriskan. Sediaan ditetesi $100 \mu \mathrm{l}$ antibodi sekunder (Biotin) dan diinkubasi pada nampan lembab yang ditutupi alumunium foil pada suhu kamar selama 20 menit. Sediaan dicuci dengan PBS sebanyak 3 kali masing-masing selama 2 menit lalu ditiriskan. Konjugat streptavidin-peroxidase diteteskan sebanyak $100 \mu \mathrm{l}$ lalu diinkubasi selama 10 menit pada suhu kamar. Preparat dicuci dengan PBS sebanyak 3 kali dengan masing-masing waktu pencucian 2 menit lalu ditiriskan. Larutan substrat kromogen
$D A B$ diteteskan sebanyak $100 \mu \mathrm{l} /$ preparat, kemudian diinkubasikan selama 10 menit dan preparat dicuci dengan aquades. Cat Mayer hematoxylin sebanyak $100 \mu \mathrm{l}$ ditambahkan per preparat, kemudian diinkubasi selama 2 menit, lalu dicuci di bawah air kran, kemudian dibilas dengan PBS 1 kali selama 1 menit. Preparat ditiriskan dan dicuci dengan air kran, kemudian aquades. Preparat didehidrasi dengan alkohol 100\%, selanjutnya dikeringkan dan dibersihkan. Selanjutnya, dicelupkan ke dalam xylol, dikeringkan dan dibersihkan. Preparat ditetesi entellan kemudian ditutup kaca penutup. Setelah kering, preparat siap diperiksa di bawah mikroskop pada pembesaran 40x, 100x, 400x, dan 1000x.

\section{HASIL PENELITIAN}

Telur yang diperoleh dari lokasi penelitian dipelihara sampai menjadi nyamuk dewasa. Nyamuk yang berhasil hidup berjumlah 48 ekor nyamuk, kemudian diidentifikasi terlebih dahulu sebelum diperiksa terinfeksi virus Dengue atau tidak. Hasil identifikasi virus Dengue dengan metode imunositokimia pada sediaan head squash nyamuk Ae. aegypti yang dipelihara dari telur (Gambar 1).

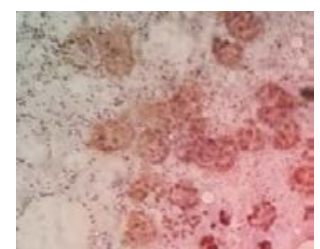

A

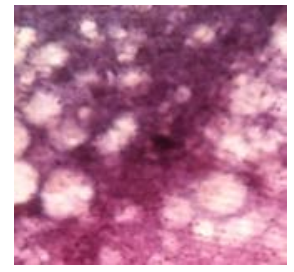

C

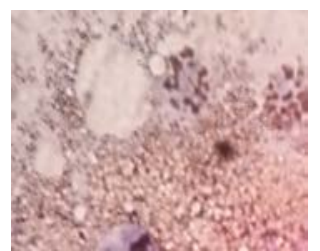

B

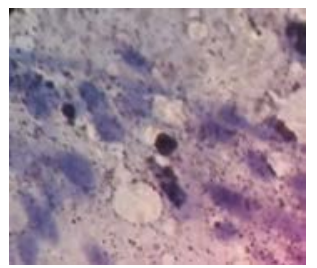

D
Gambar 1. Gambaran mikroskopis sediaan head squash nyamuk Ae. aegypti dengan metode imunositokimia pada pembesaran 1000x memperlihatkan reaksi positif pada kontrol positif (A); sampel positif Aedes aegypti (B); reaksi negatif pada kontrol negatif (C); sampel negatif Aedes aegypti (D). 
Pada sediaan head squash nyamuk Aedes aegypti yang terinfeksi virus Dengue terlihat adanya reaksi positif. Reaksi positif tersebut berupa sitoplasma sel yang berwarna coklat dan tersebar di antara jaringan otak. Sediaan kontrol negatif memperlihatkan reaksi negatif berupa sitoplasma sel yang berwarna biru dan tidak ada butiran pasir berwarna coklat di sekitar sel-sel jaringan otak.

Hasil pemeriksaan virus Dengue pada nyamuk dewasa Aedes aegypti yang positif virus Dengue disajikan pada Tabel 1.

Tabel 1. Hasil Pemeriksaan Nyamuk Aedes aegypti yang Positif Virus Dengue dengan Metode Imunositokimia beserta Index Transmisi Transovarial (ITT) di Kelurahan Kombos Barat Kecamatan Singkil Tahun 2016

\begin{tabular}{|c|c|c|c|}
\hline $\begin{array}{c}\text { Rumah } \\
\text { kasus }\end{array}$ & $\begin{array}{c}\text { Jumlah } \\
\text { Nyamuk } \\
\text { Aedes } \\
\text { aegypti } \\
\text { yang } \\
\text { diperiksa }\end{array}$ & $\begin{array}{c}\text { Jumlah } \\
\text { Nyamuk } \\
\text { Positif } \\
\text { Virus } \\
\text { Dengue }\end{array}$ & $\begin{array}{c}\text { Index } \\
\text { Transmisi } \\
\text { Transovarial } \\
\text { (ITT) }\end{array}$ \\
\hline 1 & 7 & 3 & $42,8 \%$ \\
\hline 2 & 10 & 7 & $70 \%$ \\
\hline 3 & 23 & 9 & $39,1 \%$ \\
\hline 4 & 8 & 5 & $62,5 \%$ \\
\hline & \multicolumn{2}{|c|}{ Rata-rata ITT } & $53,6 \%$ \\
\hline
\end{tabular}

Tabel 1 menunjukkan bahwa terjadi transmisi transovarial pada nyamuk Aedes aegypti di Kelurahan Kombos Barat Kecamatan Singkil Kota Manado. Hasil pemeriksaan nyamuk Aedes aegypti yang positif virus Dengue berjumlah 24 ekor nyamuk dari 48 ekor nyamuk yang diperiksa, dengan Index Transmisi Transovarial (ITT) berkisar 39,1\% - 70\%. Jumlah nyamuk yang diperiksa paling banyak dari rumah kasus ke-3 yaitu sebanyak 23 ekor dan 9 ekor nyamuk tersebut positif virus Dengue, serta Index Transmisi Transovarial terbesar adalah rumah kasus ke-2 yaitu sebesar 70\%.

\section{BAHASAN}

Sampel telur yang diambil dari tempat tinggal empat kasus DBD di Kelurahan Kombos Barat Kecamatan Singkil Kota Manado. Setelah dibiakkan di laboratorium diperoleh 48 ekor nyamuk Aedes aegypti. Pemeriksaan virus Dengue pada nyamuk Aedes aegypti menggunakan teknik imunositokimia menunjukkan bahwa 24 ekor nyamuk positif virus Dengue dari 48 ekor nyamuk yang diperiksa.

Pemeriksaan virus Dengue dengan metode imunositokimia menggunakan sediaan pencet kepala (head squash). Pada kepala nyamuk terdapat bagian yang amat penting untuk berkembang dan beramplifikasi virus dengue, yaitu sel-sel glandula salivarius dan ovarium. Hal ini didukung oleh teori yang menunjukkan adanya perubahan bentuk secara morfologi dan histologi dibandingkan dengan nyamuk yang sehat atau tidak ditulari virus. Kedua organ nyamuk tersebut terlihat jauh lebih besar (membengkak). ${ }^{9}$

Antigen virus Dengue yang terlokalisir di sel-sel glandula salivarius yang sudah bercampur dengan sel-sel jaringan otak pada sediaan head squash akan berikatan dengan antibodi monoklonal anti virus Dengue DSSE10 dan akan dikenali oleh antibodi sekunder (Biotin). Selanjutnya konjugat streptavidin dan larutan substrat kromogen yang ditambahkan pada sediaan dapat mendeteksi munculnya granula berwarna kecoklatan di sekitar sel yang terinfeksi. Hal ini sesuai dengan gambar 7B yang memperlihatkan reaksi positif pada sediaan head squash nyamuk Aedes aegypti berupa sitoplasma sel yang berwarna coklat dan tersebar di antara jaringan otak.

Hasil negatif pada deteksi tersebut ditunjukkan dengan adanya warna biru, ini disebabkan adanya penambahan hematoksilin sebagai counterstain. Hasil negatif pada pemeriksaan ini diperlihatkan pada gambar 7D berupa sitoplasma sel yang berwarna biru dan tidak ada butiran pasir berwarna coklat di sekitar sel-sel jaringan otak.

Hasil deteksi virus Dengue dengan teknik imunositokimia tersebut, memperlihatkan adanya antigen virus Dengue pada nyamuk Aedes aegypti hasil kolonisasi stadium telur yang diambil dari tempat tinggal empat kasus DBD di 
Kelurahan Kombos Barat Kecamatan Singkil Kota Manado.

Hasil pemeriksaan tersebut dapat dilihat pada tabel 1, yang menunjukkan bahwa nyamuk Aedes aegypti yang positif virus Dengue berjumlah 24 ekor nyamuk dari 48 ekor nyamuk yang diperiksa, dengan Index Transmisi Transovarial ratarata dari empat kasus adalah 53,6\%. Jumlah nyamuk Aedes aegypti yang diperiksa paling banyak adalah rumah kasus ke-3 yaitu sebanyak 23 ekor dan 9 ekor nyamuk tersebut positif virus Dengue, dengan ITT sebesar 39,1\%. ITT terbesar dari empat kasus tersebut adalah rumah kasus ke-2 sebesar 70\%, dengan total nyamuk Aedes aegypti yang diperiksa lebih sedikit dari rumah kasus ke-3, yaitu 10 ekor nyamuk dan yang positif virus Dengue berjumlah 7 ekor nyamuk.

Data tersebut memperlihatkan bahwa keberadaan virus Dengue terpelihara secara vertikal (transovarial) di Kelurahan Kombos Barat Kecamatan Singkil Kota Manado. Besarnya nilai Index Transmisi Transovarial (ITT) menunjukkan seberapa besar potensi transmisi transovarial virus Dengue. Banyaknya jumlah nyamuk Aedes aegypti tidak menentukan potensi transmisi transovarial virus Dengue. Hal ini disebabkan karena virus Dengue termasuk virus yang labil terhadap suhu dan kelembaban udara. Suhu yang relatif rendah atau relatif tinggi, serta kelembaban udara yang rendah dapat mengurangi viabilitas virus Dengue yang hidup dalam tubuh nyamuk maupun juga mengurangi viabilitas nyamuk itu sendiri. ${ }^{8}$

Berdasarkan hasil survei, rumah kasus ke-2 dan ke-3 memiliki kelembaban udara yang berbeda. Pada rumah kasus ke-2, dilihat dari kondisi lingkungan rumah yang gelap dan berhimpitan dengan beberapa rumah disekitarnya menyebabkan kelembaban udara di lingkungan rumah tersebut relatif rendah. Sedangkan pada rumah kasus ke-3, meskipun kondisi lingkungan rumah yang juga gelap namun masih ada jarak antar rumah kasus dengan rumah di sekitarnya, sehingga kelembaban udara pada rumah kasus ke-3 tidak serendah di rumah kasus ke-2. Hal ini yang menyebabkan virus Dengue dalam tubuh nyamuk di rumah kasus ke-2 lebih terpelihara daripada di rumah kasus ke-3.

Kajian mengenai Transovarial Infection Rate (TIR) virus Dengue pertama kali dilaporkan oleh Seran MD dkk pada tahun 2012 di Yogyakarta, dengan hasil penelitian adanya transmisi transovarial virus Dengue pada telur Aedes Aegypti yang terlihat pada sediaan egg squash berupa warna kecoklatan yang menyebar pada jaringan embrio, dengan TIR sebesar 52\%. Virus Dengue mampu ditransmisikan lewat telur dengan TIR 52\%.

Penelitian yang sama juga dilakukan pada tahun 2013 oleh Angle Sorisi dkk di Malalayang yang menunjukkan adanya transmisi transovarial virus Dengue pada nyamuk Aedes, dengan Index Transmisi Transovarial (ITT) berkisar 6,1\% - 17,1\%. ${ }^{6}$ Pada tahun yang sama di Kabupaten Banjarnegara, Pramestuti dkk melaporkan bahwa transmisi transovarial virus Dengue pada nyamuk terjadi pada 21 ekor nyamuk positif antigen virus Dengue dari 223 ekor nyamuk yang diperiksa. ${ }^{10}$

Ditemukannya fenomena transmisi transovarial pada nyamuk Aedes aegypti di Kelurahan Kombos Barat Kecamatan Singkil Kota Manado ini patut untuk mendapatkan perhatian khusus karena Kelurahan Kombos Barat merupakan wilayah endemis DBD. Hasil penelitian sebelumnya menyebutkan bahwa transmisi transovarial virus Dengue merupakan fenomena etiologi penting yang bertanggung jawab atas pemeliharaan virus selama periode inter-epidemi penyakit. ${ }^{10}$

Deteksi transmisi transovarial virus Dengue pada nyamuk vektor dapat menjadi salah satu bagian penting dalam kegiatan survei epidemiologi penyakit DBD, serta dapat digunakan dalam pengembangan untuk melengkapi sistem kewaspadaan dini dalam mengantisipasi tersebarnya penularan virus Dengue pada manusia dan munculnya kasus DBD baru yang sebelumnya tidak terdapat kasus DBD. 


\section{SIMPULAN}

Berdasarkan hasil penelitian yang dilakukan untuk mendeteksi keberadaan virus Dengue pada nyamuk Aedes aegypti dengan menggunakan teknik imunositokimia, terbukti bahwa ada potensi nyamuk Aedes aegypti menularkan virus Dengue secara transmisi transovarial di Kelurahan Kombos Barat Kecamatan Singkil Kota Manado.

\section{DAFTAR PUSTAKA}

1. Sari TF, Umniyati SR. Sensitivitas dan Spesifitas Antibodi Monoklonal DSSE10 pada Head Squash Toxorhynchites Splendens dengan Teknik Imunohistokimia. Jurnal Vektora. Vol IV, No 2, 2011:124.

2. Natadisastra D, Agoes R. Parasitologi Kedokteran: Ditinjau dari Organ Tubuh yang Diserang. Jakarta: EGC; 2009. h. 315-7.

3. Kementerian Kesehatan Republik Indonesia 2015. Data dan Informasi Tahun 2014 (Profil Kesehatan Indonesia). 2015 [cited 2015 Oct 10].

4. Kewo I, Rambert G, Manoppo F. Karakteristik Eritrosit pada Pasien Anak dengan Infeksi Virus Dengue di Manado. eBm. Vol.3, No.2, 2015:567.

5. Seran MD, Prasetyowati H. Transmisi Transovarial Virus Dengue pada Telur Nyamuk Aedes aegypti. Aspirator. Vol.4, No.2, 2012:53-8.
6. Sorisi AMH, Umniyati SR, Sartoto TBT. Transovarial Transmission Index of Dengue Virus on Aedes aegypti and Aedes albopictus Mosquitoes in Malalayang District in Manado, North Sulawesi, Indonesia. TMJ. Vol.04, No.02, 2013:87-95.

7. Tjahjasari Andi Mulia. Deteksi dan Penentuan Serotipe Virus Dengue Tipe 4 dari Nyamuk Aedes aegypti dengan Menggunakan Metode Reverse Transcriptase-Polymerase Chain Reaction (RT-PCR) [Tesis]. [Medan]: Universitas Sumatera Utara; 2009.

8. Palgunadi DU, Rahayu A. Aedes aegypti sebagai Vektor Penyakit Demam Berdarah Dengue. 2011 [cited 2015 Oct 11]. Available from: https://elib,fk,uwks.ac.id/asset/archie ve/jurnal/vol2.n01.Januari2011.pdf

9. Syukur Abdul. Analisis Spasial Faktor Resiko Lingkungan terhadap Kejadian Demam Berdarah Dengue (DBD) di Kabupaten Sambas Provinsi Kalimantan Barat [Tesis]. [Semarang]: Universitas Diponegoro Semarang; 2012.

10.Pramestuti N, Widiastuti D, Raharjo J. Transmisi Trans-ovari Virus Dengue pada Nyamuk Aedes aegypti dan Aedes albopictus di Kabupaten Banjarnegara. Jurnal Ekologi Kesehatan. Vol 12. No.3, 2013:18794. 